\title{
Effect of Bio-Inoculants on Growth, Dry Root Yield and Quality in Ashwagandha (Withania somnifera L. Dunal.)
}

\author{
T. Pramodkumar ${ }^{1 *}$, Mukund Shiragur ${ }^{2}$ and B. Chandrakant ${ }^{1}$ \\ ${ }^{1}$ Department of Plantation, Spices, Medicinal and Aromatic Plants, ${ }^{2}$ Department of FLA, KRC \\ College of Horticulture, Arabhavi 591218, Tal Gokak, Belgaum, Karnataka, India
}

*Corresponding author

\section{Keywords}

Ashwagandha or Asgandh (Withania somnifera $\mathrm{L}$.

Dunal.), Dry root

\section{Article Info}

Accepted:

16 August 2018

Available Online:

10 September 2018

\section{A B S T R A C T}

An investigation was carried out to study the effect of bio-inoculants (Azatobacter, Azospirillum, PSB and VAM) on growth, yield and quality of ashwagandha by comparing with RDF at K.R.C.C.H. College of Arabhavi. The results showed that growth parameters viz., plant height $(74.20 \mathrm{~cm})$, stem diameter $(0.85 \mathrm{~cm})$, plant spread $(\mathrm{N}-\mathrm{S}(37.60 \mathrm{~cm})$ and $\mathrm{E}-\mathrm{W}(38.07 \mathrm{~cm}))$ and number of primary branches (8.80) recorded maximum with the application of RDF + VAM and yield parameters viz., number of berries per plant (219.33), seed yield ( $3.15 \mathrm{q} / \mathrm{ha})$, fresh root $(19.58 \mathrm{q} / \mathrm{ha})$ and dry root yield $(5.88 \mathrm{q} / \mathrm{ha})$ recorded maximum with the application of $\mathrm{RDF}+\mathrm{VAM}$, however the organic treatment $\mathrm{T}_{7}$ have shown on par results in growth and yield parameters. Quality parameter like root length and root diameter recorded maximum $(27.07 \mathrm{~cm}$, $1.88 \mathrm{~cm}$, respectively) in $\mathrm{T}_{3}-\mathrm{RDF}(\mathrm{N}: \mathrm{P}: \mathrm{K}-40: 50: 40 \mathrm{~kg} / \mathrm{ha})+\mathrm{FYM}(5 \mathrm{t} / \mathrm{ha})+\mathrm{VAM}(25 \mathrm{~kg} / \mathrm{ha})$, which was on par results of $\mathrm{T}_{1}, \mathrm{~T}_{7}$ and $\mathrm{T}_{5}$. Maximum total alkaloid content $(0.31 \%)$ recorded in $\mathrm{T}_{7}$-FYM (5 t/ha) + Azotobacter (625 g/ha) + Azospirillum (625 g/ha) + PSB (625 g/ha) + VAM $(25 \mathrm{~kg} / \mathrm{ha})+($ Panchagavya-3\% + Amruthapani-3\% at 15 days interval up to harvest of crop), however treatments $\mathrm{T}_{3}, \mathrm{~T}_{1}$ and $\mathrm{T}_{5}$ have shown on par results. The highest organic carbon $(0.63 \%)$ was recorded in treatment $\mathrm{T}_{7}$-FYM $(5 \mathrm{t} / \mathrm{ha})+$ Azotobacter $(625 \mathrm{~g} / \mathrm{ha})+$ Azospirillum $(625 \mathrm{~g} / \mathrm{ha})+$ PSB $(625 \mathrm{~g} / \mathrm{ha})+\mathrm{VAM}(25 \mathrm{~kg} / \mathrm{ha})+($ Panchagavya-3\% + Amruthapani-3\% at 15 days interval up to harvest of crop. Maximum soil $\mathrm{pH}$ (7.72) was recorded in treatment in $\mathrm{T}_{3^{-}}$ RDF (N: P: K-40:50:40 kg/ha) + FYM (5 t/ha) + VAM (25 kg/ha). Maximum soil electrical conductivity $(0.51 \mathrm{dS} / \mathrm{m})$ was recorded in treatment $\mathrm{T}_{1}$-RDF $(\mathrm{N}: \mathrm{P}: \mathrm{K}-40: 50: 40 \mathrm{~kg} / \mathrm{ha})+\mathrm{FYM}$ (5 t/ha). The available nutrient status in soil differed significantly among different treatments. The highest available nitrogen, phosphorus and potassium $(159.67,32.08$ and $163.44 \mathrm{~kg} / \mathrm{ha}$ respectively) recorded in $\mathrm{T}_{7}$-FYM (5 t/ha) + Azotobacter (625 g/ha) + Azospirillum (625 g/ha) + PSB (625 g/ha) + VAM (25 kg/ha) + (Panchagavya-3\% + Amruthapani-3\% at 15 days interval up to harvest of crop). Maximum bacterial population $\left(134 \times 10^{6}\right)$, fungi $\left(124 \times 10^{3}\right)$, Azotobacter chroococcum $\left(174.25 \times 10^{4}\right)$, Azospirillum brasilense $\left(192.23 \times 10^{4}\right)$, Phosphate solubilising bacteria $\left(178.46 \times 10^{6}\right)$, root colonization $(82 \%)$ and number of chlamydospores (3174.50/ $100 \mathrm{~g}$ of soil) were obtained in the treatment $\mathrm{T}_{7}$-FYM (5 t/ha) + Azotobacter $(625$ $\mathrm{g} / \mathrm{ha})+$ Azospirillum (625 g/ha) + PSB (625 g/ha) + VAM (25 kg/ha) + (Panchagavya-3\% + Amruthapani-3\% at 15 days interval up to harvest of crop), followed by treatments $\mathrm{T}_{6}$-FYM (5 $\mathrm{t} / \mathrm{ha})+$ Azotobacter (625g/ha) + Azospirillum (625g/ha) + PSB (625g/ha) + VAM (25 kg/ha). As bio-fertilizers are eco-friendly and helps in maintaining the harmony with the nature, at the same time helps to obtain higher yields with higher productivity. 


\section{Introduction}

Ashwagandha or Asgandh (Withania somnifera L. Dunal.) popularly known as 'Indian Ginseng' belongs to the family Solanaceae. It is found in wild state in the Mediterranean region of North Africa. In India it is mainly cultivated in Mandsaur district of Madhya Pradesh, adjoining villages of Kota district of Rajasthan, Punjab and Karnataka. Ashwagandha roots and occasionally its leaf and seeds are used in ayurvedic and unani medicines preparations. (Majumdar, 1955). The total alkaloid content of the Indian ashwagandha roots is reported to vary between 0.13 to 0.31 per cent. Apart from roots, alkaloids have also been reported in leaves and berries (Sreerekha et al., 2004). The roots are prescribed in medicines for hiccup, several female disorders, bronchitis, rheumatism, dropsy and stomach, lung inflammation and skin diseases.

They are mostly used for curing general and sexual disabilities. Roots are having anti-aging property (Savitha et al., 2009). The leaves are used to cure eye boils, and swellings of hands and feet, in treatment of syphilis, to kill the lice infecting the body. The leaf decoction is used for treatment of haemorrhoids and arthritis.

\section{Materials and Methods}

The field experiment was carried out in the division of plantation, Spices, Medicinal and Aromatic Crops, college of horticulture, Arabhavi during 2016-2017. The experiment was laid out in randomized block design with 7 treatments viz., $\mathrm{T}_{1}$-Recommended dose of fertilizers (N: P: K- 40:50:40 kg/ha) + FYM (5 t/ha), $\mathrm{T}_{2}-\mathrm{FYM}$ (5 t/ha) + Vermicompost-1.33 $\mathrm{t} / \mathrm{ha}$ ( $\mathrm{N}$ equivalent weight), $\mathrm{T}_{3}-\mathrm{T}_{1}+\mathrm{VAM}(25$ $\mathrm{kg} / \mathrm{ha}), \mathrm{T}_{4}-\mathrm{FYM}$ (5 t/ha) + VAM (25 kg/ha), $\mathrm{T}_{5^{-}}$FYM (5 t/ha) + VAM (25 kg/ha) + (Panchagavya-3\% + Amruthapani-3\% at 15 days' interval up to harvest crop), $\mathrm{T}_{6}$-FYM (5 t/ha) + Azotobacter (625 g/ha) + Azospirillum $(625 \mathrm{~g} / \mathrm{ha})+$ PSB $(625 \mathrm{~g} / \mathrm{ha})+\mathrm{VAM}(25$ $\mathrm{kg} / \mathrm{ha}$ ) and $\mathrm{T}_{7-} \mathrm{T}_{6}+$ (Panchagavya-3\%+ Amruthapani-3\% at 15 days' interval up to harvest of crop) and 3 replications. The spacing followed was $30 \times 20 \mathrm{~cm}$.

\section{Seed treatment with bio-fertlizers and sowing}

Azospirillum brasilense, Azotobacter chroococcum, Phosphate solublising bacteria were obtained from Department of Agricultural Microbiology, Dharwad. Azospirillum brasilense, Azotobacter chroococcum, Phosphate solublising bacteria were applied as seed treatment. Bio-fertlizers culture suspension was prepared by using 625 $\mathrm{g}$ per ha of Azotobacter chroococcum, Azospirillum brasilense, Phosphate solublising bacteria and mixed in water at a ratio of $1: 2$ and with adding jaggary which acts as sticker. Then the seeds were shade dried overnight and then seeds were sown at a spacing of $30 \times 20$ $\mathrm{cm}$. Light irrigation was provided immediately after sowing.

\section{Inoculation with AM fungus}

Culture of Vesicular Arbuscular Mycorrhizal fungus (VAM) Entrophospora sp. was obtained from Department of Agricultural Microbiology, Kittur Rani Channamma College of Horticulture, Arabhavi. The inoculum was multiplied in sterilized potting mixture using maize (Zea mays) as host plant in the shade house of Microbiology Department.

The inoculum used consisted of sand and soil in 1:1 proportion and root segments of maize comprising of hyphae, vescicles, arbuscules and chlamydospore of AM fungus, Entrophospora sp. Five grams of inoculum was applied per seed before sowing. 


\section{Results and Discussion}

Maximum plant height, stem diameter, plant spread (N-S \& E-W) and number of primary branches $(74.20 \mathrm{~cm}, 0.85 \mathrm{~cm},(37.60 \mathrm{~cm}$, $38.07 \mathrm{~cm}$ ) and 8.80, respectively), were recorded in the treatment $\mathrm{T}_{3}$-Recommended dose of fertilizers (N:P:K- 40:50:40 kg/ha) + FYM (5t/ha) + VAM (25 kg/ha), which was on par with $\mathrm{T}_{1}(68.53 \mathrm{~cm}, 0.84 \mathrm{~cm},(35.07 \mathrm{~cm}$ and $36.67 \mathrm{~cm}$ ) and 8.40 , respectively), $\mathrm{T}_{7}$ $(67.67 \mathrm{~cm}, 0.84 \mathrm{~cm},(35.00 \mathrm{~cm}$ and $37.00 \mathrm{~cm})$ and 8.20 , respectively) and $\mathrm{T}_{5}(63.47 \mathrm{~cm}, 0.83$ $\mathrm{cm},(34.27 \mathrm{~cm}$ and $33.00 \mathrm{~cm})$ and 8.13 , respectively). This increasing trend in morphological parameters might be due to recommended dose of fertilizer along with VAM recorded significantly higher values for morphological parameters. It could be attributed to the quick and readily availability of major nutrients like N, P and $\mathrm{K}$ to plants at earlier stages of plant growth. The results obtained in the present investigation are in agreement with earlier findings of Rana et al., (2005), Snezana et al., (2012) in buckwheat and Shinde et al., (2013) in ashwagandha.

However the organic treatment $\mathrm{T}_{7}-\mathrm{FYM}$ (5 $\mathrm{t} / \mathrm{ha})+$ Azotobacter $(625 \mathrm{~g} / \mathrm{ha})+$ Azospirillum $(625 \mathrm{~g} / \mathrm{ha})+$ PSB $(625 \mathrm{~g} / \mathrm{ha})+$ VAM $(25$ $\mathrm{kg} / \mathrm{ha}$ ) + (Panchagavya-3\% + Amruthapani-3\% at 15 days interval) has also shown better result, this might be due to the reason that, their built up in the beneficial soil microbial population at the rhizosphere and regular addition of bio-formulations especially by the synergetic effect drench both of panchagavya and amrutpani have lead to the effective supply of nutrients and acting as source of PGPR (Plant Growth Promoting Rhizobacteria). This had helped to improve nutrient availability to the plants and also by arbuscular mycorrhizal fungi, due to their ability to increase nutrient uptake and water transport. The results obtained in the present investigation are in agreement with earlier findings of Sakhubai et al., (2014) in buckwheat, Ravikumar et al., (2012) in coleus and Vajantha et al., (2014) in ashwagandha.

Number of berries per node and seed yield were significantly influenced by application of organic manures and bio-inoculants. At harvest, maximum number of berries per plant (219.33) was recorded in $\mathrm{T}_{3}$-Recommended dose of fertilizers (N:P:K-40:50:40 kg/ha) + FYM (5 t/ha) + VAM ( $25 \mathrm{~kg} / \mathrm{ha})$, it was on par with $\mathrm{T}_{1}$ (213.33/plant), $\mathrm{T}_{7}$ (211.67/plant) and $\mathrm{T}_{5} \quad$ (210.13/plant).There was appreciable increase in the number of berries per plant due to excellent growth and development of root and shoot particularly more assimilatory area on account of balanced and timely supply of all the essential nutrients which in turn led to better partitioning of photosynthates from source to the sink (seeds). Similar results have been reported by Shrivatsav and Sahu (2013) in ashwagandha.

Seed yield was influenced with application of organic manures and bio-inoculants. At harvest maximum seed yield $(2.83 \mathrm{~g} /$ plant, $0.23 \mathrm{~kg} / \mathrm{plot}$ and $3.15 \mathrm{q} / \mathrm{ha}$ ) was obtained in $\mathrm{T}_{3}$-Recommended dose of fertilizers (N:P:K40:50:40 kg/ha) + FYM (5 t/ha) + VAM (25 $\mathrm{kg} / \mathrm{ha})$, it was on par with $\mathrm{T}_{1}(2.78 \mathrm{~g} / \mathrm{plant}$, $0.22 \mathrm{~kg} / \mathrm{plot}$ and $3.09 \mathrm{q} / \mathrm{ha})$ and $\mathrm{T}_{7}(2.73$ $\mathrm{g} /$ plant, $0.22 \mathrm{~kg} / \mathrm{plot}$ and $3.0 \mathrm{q} / \mathrm{ha})$. The enhanced seed yield in particular treatment might be due to availability of nutrients in the soil throughout the growing phase and also due to enhanced carbohydrates synthesis and effective translocation of the photosynthates to the sink and the results are in line with the findings of with Pakkiyanthan et al., (2004), Panchabhai et al., (2005) in ashwagandha. Immediate supply of plant nutrients by inorganic sources has enhanced seed yield were realized.

At harvest fresh and dry root yield were significantly influenced by treatments. The 
highest fresh root yield (17.60 g/plant, 1.41 $\mathrm{kg} / \mathrm{plot}$ and $19.58 \mathrm{q} / \mathrm{ha}$ ) was recorded in $\mathrm{T}_{3^{-}}$ Recommended dose of fertilizers (N:P:K40:50:40 kg/ha) + FYM (5 t/ha) + VAM (25 $\mathrm{kg} / \mathrm{ha})$, it was on par with $\mathrm{T}_{1}(17.55 \mathrm{~g} / \mathrm{plant}$, $1.40 \mathrm{~kg} / \mathrm{plot}$ and $19.50 \mathrm{q} / \mathrm{ha}), \mathrm{T}_{7}$ (17.54 g/plant, $1.40 \mathrm{~kg} / \mathrm{plot}$ and $19.49 \mathrm{q} / \mathrm{ha}), \mathrm{T}_{5}$ $(17.25 \mathrm{~g} / \mathrm{plant}, 1.38 \mathrm{~kg} / \mathrm{plot}$ and $19.12 \mathrm{q} / \mathrm{ha})$ and $\mathrm{T}_{6}(16.77 \mathrm{~g} /$ plant, $1.34 \mathrm{~kg} / \mathrm{plot}$ and 18.61 $\mathrm{q} / \mathrm{ha}$ ) recorded. Highest dry root yield (5.29 $\mathrm{g} /$ plant, $0.42 \mathrm{~kg} / \mathrm{plot}$ and $5.88 \mathrm{q} / \mathrm{ha}$ ) recorded in $\mathrm{T}_{3}$-Recommended dose of fertilizers $(\mathrm{N}: \mathrm{P}: \mathrm{K}-40: 50: 40 \mathrm{~kg} / \mathrm{ha})+\mathrm{FYM}(5 \mathrm{t} / \mathrm{ha})+$ VAM $(25 \mathrm{~kg} / \mathrm{ha})$ it was on par with $\mathrm{T}_{1}(4.75$ g/plant, $0.38 \mathrm{~kg} /$ plot and $5.27 \mathrm{q} / \mathrm{ha})$ and $\mathrm{T}_{7}$ (4.69 g/plant, $0.36 \mathrm{~kg} / \mathrm{plot}$ and $5.00 \mathrm{q} / \mathrm{ha})$.

The combined application of inorganic fertilizer and organic manures (FYM) might have supplied adequate amount of nutrients, favoured metabolic rate, auxin activities in the plant, resulting in better yield attributes and higher root yield. These results are in agreement with Maheshwari et al., (2000), Ajay et al., (2005) in ashwagandha and Somanath et al., (2005) in coleus.

The VAM fungusand bio-formulations, increased root geometry, nutrient access and supply resulting in the development of sound and healthy rhizosphere with increased extramycelial hyphae might had further contributed to improved growth resulting in increased nutrient uptake, photosynthesis and excellent biochemical activities. Similar results were also reported Sakhubai et al., (2014) in buckwheat and Ravikumar et al., (2010) in coleus, Vajantha et al., (2014) in ashwagandha.

Significant difference was observed in root length and root diameter due to application of organic manures and bio-inoculants. At harvest, maximum root length $(27.07 \mathrm{~cm})$ and root diameter $(1.88 \mathrm{~cm})$ were recorded in $\mathrm{T}_{3^{-}}$ Recommended dose of fertilizers $(\mathrm{N}$ : P: K-
40:50:40 kg/ha) + FYM (5 t/ha) + VAM (25 $\mathrm{kg} / \mathrm{ha})$. It was on par with $\mathrm{T}_{1}(26.47 \mathrm{~cm}, 1.84$ $\mathrm{cm}$ of root length and root diameter, respectively), $\mathrm{T}_{7}(26.13 \mathrm{~cm}, 1.83 \mathrm{~cm}$ of root length and root diameter, respectively) and $\mathrm{T}_{5}$ $(24.27 \mathrm{~cm}, 1.81 \mathrm{~cm}$ of root length and root diameter, respectively).This might be due to the favourable soil condition by the incorporation of organic manures and further, the inorganic fertilizers would have created congenial condition for better uptake of nutrients and better development of root length and root diameter. These results are in conformity with Rashmi (2013) in ashwagandha, Somnath et al., (2005) and Ravikumar et al., (2012) in coleus and Sandhya et al., (2013) in Marsdenia volubilis.

Alkaloid content differed significantly due to application of organic manures bio-inoculants (Table 3). Maximum alkaloid content $(0.31 \%)$ was recorded with application of $\mathrm{T}_{7}-\mathrm{FYM}(5$ $\mathrm{t} / \mathrm{ha})+$ Azotobacter $(625 \mathrm{~g} / \mathrm{ha})+$ Azospirillum $(625 \mathrm{~g} / \mathrm{ha})+$ PSB $(625 \mathrm{~g} / \mathrm{ha})+$ VAM $(25$ $\mathrm{kg} / \mathrm{ha})+($ Panchagavya-3\% + Amruthapani$3 \%$ at 15 days interval), it was on par with $\mathrm{T}_{3}$ (0.29\%), $\quad \mathrm{T}_{1}(0.27 \%)$ and $\mathrm{T}_{5} \quad(0.26 \%)$. Favourable soil condition due to the incorporation of organic and a bio-inoculants nutrient source were congenial for better development of root. This might have resulted in higher alkaloid accumulation. The results obtained in the present investigation are in agreement with earlier findings of Rajamani et al., (2007) in turmeric, Das et al., (2008) in stevia, Ravikumar et al., (2012) in coleus and Sandhya et al., (2013) in Marsdenia volubilis, Rajasekar and Elango (2011) in ashwagandha.

Soil $\mathrm{pH}$, electrical conductivity and organic carbon varied significantly among different treatments. Maximum soil $\mathrm{pH}$ (7.72) was observed in soil $\mathrm{T}_{3}$-Recommended dose of fertilizers (N: P: K-40:50:40 kg/ha) + FYM (5 $\mathrm{t} / \mathrm{ha})+\mathrm{VAM}(25 \mathrm{~kg} / \mathrm{ha})$, it was on par with $\mathrm{T}_{1}$ (7.70) (Table 1-6). 
Table.1 Growth of ashwagandha at 150 Days After Sowing

\begin{tabular}{|c|c|c|c|c|c|}
\hline \multirow[t]{2}{*}{ Treatments } & \multirow{2}{*}{$\begin{array}{l}\text { Plant } \\
\text { height } \\
(\mathrm{cm})\end{array}$} & \multirow{2}{*}{$\begin{array}{l}\text { Stem } \\
\text { diamete } \\
\mathbf{r}(\mathbf{c m})\end{array}$} & \multicolumn{2}{|c|}{ Plant spread } & \multirow{2}{*}{$\begin{array}{c}\text { Number of } \\
\text { primary } \\
\text { branches }\end{array}$} \\
\hline & & & $\begin{array}{r}(\mathrm{N}-\mathrm{S}) \\
(\mathrm{cm})\end{array}$ & $\begin{array}{c}(\mathrm{E}-\mathrm{W}) \\
(\mathrm{cm})\end{array}$ & \\
\hline $\begin{array}{l}T_{1}-\text { Recommended dose of fertilizers (control) } \\
\text { N:P:K-40:50:40 kg per ha + FYM-5 t/ha }\end{array}$ & 68.53 & 0.84 & 35.07 & 36.67 & 8.40 \\
\hline $\begin{array}{l}T_{2} \text { - FYM ( } 5 \text { t/ha) +Vermicompost-1.33 t/ha ( } N \\
\text { equivalent weight) }\end{array}$ & 54.53 & 0.73 & 24.33 & 25.13 & 7.27 \\
\hline$T_{3}-T_{1}+$ VAM (25 kg/ha) & 74.20 & 0.85 & 37.60 & 38.07 & 8.80 \\
\hline $\mathrm{T}_{4}$-FYM $(5 \mathrm{t} / \mathrm{ha})+$ VAM $(25 \mathrm{~kg} / \mathrm{ha})$ & 56.07 & 0.78 & 29.20 & 28.13 & 7.53 \\
\hline $\begin{array}{l}\mathrm{T}_{5}-\mathrm{FYM}(5 \mathrm{t} / \mathrm{ha})+\mathrm{VAM}(25 \mathrm{~kg} / \mathrm{ha})+ \\
\text { (Panchagavya }-3 \% \text { + Amruthapani }-3 \% \text { at } 15 \\
\text { days interval) }\end{array}$ & 63.47 & 0.83 & 34.27 & 33.00 & 8.13 \\
\hline $\begin{array}{l}\text { T}_{6} \text { FYM (5 t/ha) + Azotobacter (625 g/ha) + } \\
\text { Azospirillum (625 g/ha) + PSB (625 g/ha) + } \\
\text { VAM ( } 25 \mathrm{~kg} / \mathrm{ha})\end{array}$ & 59.40 & 0.82 & 34.00 & 29.07 & 8.07 \\
\hline $\begin{array}{l}T_{7}-T_{6}+\text { (Panchagavya }-3 \%+\text { Amruthapani }-3 \% \\
\text { at } 15 \text { days interval) }\end{array}$ & 67.67 & 0.84 & 35.00 & 37.00 & 8.20 \\
\hline Mean & 63.41 & 0.81 & 32.78 & 32.44 & 8.06 \\
\hline SEm \pm & 1.32 & 0.02 & 2.51 & 2.67 & 0.25 \\
\hline CD at $5 \%$ & 4.08 & 0.06 & 7.74 & 8.23 & 0.78 \\
\hline
\end{tabular}

Table.2 Yield of ashwagandha at after harvest

\begin{tabular}{|c|c|c|c|c|}
\hline Treatments & $\begin{array}{l}\text { Number of } \\
\text { berries/plant }\end{array}$ & $\begin{array}{c}\text { Seed yield } \\
\text { (q/ha) }\end{array}$ & $\begin{array}{l}\text { Fresh root } \\
\text { yield (q/ha) }\end{array}$ & $\begin{array}{c}\text { Dry root } \\
\text { yield }(q / h a)\end{array}$ \\
\hline $\begin{array}{l}\mathrm{T}_{1} \text {-Recommended dose of fertilizers } \\
\text { (control) N:P:K- 40:50:40 kg per ha }+ \\
\text { FYM-5 t/ha }\end{array}$ & 213.33 & 3.09 & 19.50 & 5.27 \\
\hline $\begin{array}{l}T_{2} \text { - FYM ( } 5 \text { t/ha) +Vermicompost-1.33 } \\
\text { t/ha ( } \mathrm{N} \text { equivalent weight) }\end{array}$ & 183.87 & 2.25 & 15.87 & 4.21 \\
\hline$T_{3}-T_{1}+$ VAM $(25 \mathrm{~kg} / \mathrm{ha})$ & 219.33 & 3.15 & 19.58 & 5.88 \\
\hline $\mathrm{T}_{4}$-FYM (5 t/ha) + VAM (25 kg/ha) & 192.33 & 2.38 & 17.03 & 4.41 \\
\hline $\begin{array}{l}\text { T5 }_{5} \text { FYM }(5 \mathrm{t} / \mathrm{ha})+\mathrm{VAM}(25 \mathrm{~kg} / \mathrm{ha})+ \\
\text { (Panchagavya }-3 \%+\text { Amruthapani - } \\
\text { 3\% at } 15 \text { days interval) }\end{array}$ & 210.13 & 2.71 & 19.12 & 4.72 \\
\hline $\begin{array}{l}\text { T}_{6-} \text { FYM }(5 \mathrm{t} / \mathrm{ha})+\text { Azotobacter }(625 \\
\text { g/ha) + Azospirillum }(625 \mathrm{~g} / \mathrm{ha})+\text { PSB } \\
(625 \mathrm{~g} / \mathrm{ha})+\text { VAM }(25 \mathrm{~kg} / \mathrm{ha})\end{array}$ & 208.67 & 2.45 & 18.61 & 4.58 \\
\hline $\begin{array}{l}\mathrm{T}_{7}-\mathrm{T}_{6+}+\text { (Panchagavya }-3 \% \\
\text { Amruthapani }-3 \% \text { at } 15 \text { daysinterval) }\end{array}$ & 211.67 & 3.03 & 19.49 & 5.00 \\
\hline Mean & 205.62 & 2.72 & 18.46 & 4.85 \\
\hline SEm \pm & 3.49 & 0.13 & 0.71 & 0.32 \\
\hline CD at $5 \%$ & 10.74 & 0.40 & 2.18 & 0.97 \\
\hline
\end{tabular}


Table.3 Root length (cm), root diameter $(\mathrm{cm})$ and total alkaloid content as influenced by different nutrient sources and their combination with bio-inoculants in ashwagandha

\begin{tabular}{|c|c|c|c|}
\hline Treatments & $\begin{array}{l}\text { Root length } \\
\quad(\mathrm{cm})\end{array}$ & $\begin{array}{l}\text { Root } \\
\text { diameter } \\
(\mathbf{c m})\end{array}$ & $\begin{array}{l}\text { Total } \\
\text { alkaloid } \\
\text { content }(\%)\end{array}$ \\
\hline $\begin{array}{l}T_{1} \text {-Recommended dose of fertilizers (control) } \mathrm{N}: \mathrm{P}: \mathrm{K}- \\
\text { 40:50:40 kg per ha + FYM-5 t/ha }\end{array}$ & 26.47 & 1.84 & 0.27 \\
\hline $\begin{array}{l}\mathrm{T}_{2} \text { - FYM (5 t/ha) +Vermicompost- } 1.33 \mathrm{t} / \mathrm{ha}(\mathrm{N} \\
\text { equivalent weight) }\end{array}$ & 21.03 & 1.60 & 0.20 \\
\hline $\mathrm{T}_{3^{-}} \mathrm{T}_{1}+\mathrm{VAM}(25 \mathrm{~kg} / \mathrm{ha})$ & 27.07 & 1.88 & 0.29 \\
\hline $\mathrm{T}_{4}$-FYM (5 t/ha) + VAM (25 kg/ha) & 22.73 & 1.70 & 0.22 \\
\hline 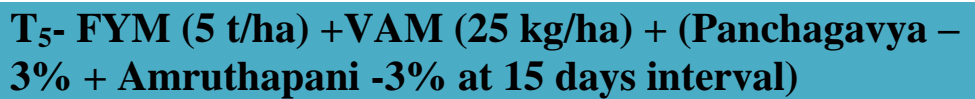 & 24.27 & 1.81 & 0.26 \\
\hline $\begin{array}{l}\left.\text { T }_{6} \text { FYM (5 t/ha }\right)+ \text { Azotobacter }(625 \mathrm{~g} / \mathrm{ha})+ \\
\text { Azospirillum }(625 \mathrm{~g} / \mathrm{ha})+\text { PSB }(625 \mathrm{~g} / \mathrm{ha})+\text { VAM }(25 \\
\mathrm{kg} / \mathrm{ha})\end{array}$ & 23.17 & 1.79 & 0.24 \\
\hline $\begin{array}{l}\mathrm{T}_{7}-\mathrm{T}_{6}+(\text { Panchagavya }-3 \%+\text { Amruthapani }-3 \% \text { at } 15 \\
\text { days interval) }\end{array}$ & 26.13 & 1.83 & 0.31 \\
\hline Mean & 24.41 & 1.78 & 0.26 \\
\hline SEm \pm & 1.02 & 0.06 & 0.02 \\
\hline CD at $5 \%$ & 3.13 & 0.18 & 0.06 \\
\hline
\end{tabular}

Table.4 Soil status after harvest crop as influenced by different nutrient sources and their combination with bio- inoculants in ashwagandha.

\begin{tabular}{|c|c|c|c|}
\hline Treatments & pH & $\begin{array}{c}\text { Electrical } \\
\text { conductivity }\left(\mathrm{dS} \mathrm{m}^{-1}\right)\end{array}$ & $\begin{array}{c}\text { Organic } \\
\text { carbon }(\%)\end{array}$ \\
\hline $\begin{array}{l}T_{1}-\text { Recommended dose of fertilizers (control) } \\
\text { N:P:K-40:50:40 kg per ha + FYM-5 t/ha }\end{array}$ & 7.70 & 0.51 & 0.40 \\
\hline $\begin{array}{l}T_{2} \text { - FYM ( } 5 \text { t/ha) +Vermicompost-1.33t/ha }(\mathrm{N} \\
\text { equivalent weight) }\end{array}$ & 7.68 & 0.49 & 0.43 \\
\hline$T_{3}-T_{1}+$ VAM $(25 \mathrm{~kg} / \mathrm{ha})$ & 7.72 & 0.50 & 0.48 \\
\hline T $_{4}$-FYM (5 t/ha) + VAM (25 kg/ha) & 7.65 & 0.48 & 0.52 \\
\hline $\begin{array}{l}\mathrm{T}_{5^{-}} \mathrm{FYM}(5 \mathrm{t} / \mathrm{ha})+\mathrm{VAM}(25 \mathrm{~kg} / \mathrm{ha})+ \\
\text { (Panchagavya }-3 \%+\text { Amruthapani }-3 \% \text { at } 15 \text { days } \\
\text { interval) }\end{array}$ & 7.62 & 0.46 & 0.60 \\
\hline $\begin{array}{l}\text { T}_{6-} \text { FYM }(5 \mathrm{t} / \mathrm{ha})+\text { Azotobacter }(625 \mathrm{~g} / \mathrm{ha})+ \\
\text { Azospirillum }(625 \mathrm{~g} / \mathrm{ha})+\text { PSB }(625 \mathrm{~g} / \mathrm{ha})+\text { VAM } \\
(25 \mathrm{~kg} / \mathrm{ha})\end{array}$ & 7.64 & 0.47 & 0.54 \\
\hline $\begin{array}{l}T_{7}-T_{6}+\text { (Panchagavya }-3 \%+\text { Amruthapani }-3 \% \text { at } \\
15 \text { days interval) }\end{array}$ & 7.60 & 0.40 & 0.63 \\
\hline Mean & 7.66 & 0.48 & 0.51 \\
\hline $\operatorname{SEm} \pm$ & 0.01 & 0.01 & 0.01 \\
\hline CD at $5 \%$ & 0.02 & 0.02 & 0.04 \\
\hline
\end{tabular}


Table.5 A vailable nutrients in soil after harvest crop as influenced by different nutrient sources and their combination with bio-inoculants in ashwagandha.

\begin{tabular}{|c|}
\hline Treatments \\
\hline $\begin{array}{l}T_{1}-\text { Recommended dose of fertilizers (control) N:P:K- } \\
\text { 40:50:40 kg per ha + FYM-5 t/ha }\end{array}$ \\
\hline $\begin{array}{l}T_{2^{-}} \text {FYM ( } 5 \text { t/ha) +Vermicompost-1.33 t/ha ( } \mathrm{N} \text { equivalent } \\
\text { weight) }\end{array}$ \\
\hline $\mathrm{T}_{3^{-}} \mathrm{T}_{1}+\mathrm{VAM}(25 \mathrm{~kg} / \mathrm{ha})$ \\
\hline $\mathrm{T}_{4}$-FYM (5 t/ha) + VAM (25 kg/ha) \\
\hline $\begin{array}{l}\left.\text { T }_{5^{-}} \text {FYM (5 t/ha) +VAM ( } 25 \mathrm{~kg} / \mathrm{ha}\right)+(\text { Panchagavya }-3 \% \\
+ \text { Amruthapani - 3\% at } 15 \text { days interval) }\end{array}$ \\
\hline $\begin{array}{l}\text { T }_{6-} \text { FYM (5 t/ha) + Azotobacter }(625 \mathrm{~g} / \mathrm{ha})+\text { Azospirillum } \\
(625 \mathrm{~g} / \mathrm{ha})+\text { PSB }(625 \mathrm{~g} / \mathrm{ha})+\text { VAM }(25 \mathrm{~kg} / \mathrm{ha})\end{array}$ \\
\hline $\begin{array}{l}\mathrm{T}_{7}-\mathrm{T}_{6}+(\text { Panchagavya }-3 \%+\text { Amruthapani }-3 \% \text { at } 15 \\
\text { days interval) }\end{array}$ \\
\hline Mean \\
\hline $\mathrm{SEm} \pm$ \\
\hline CD at $5 \%$ \\
\hline
\end{tabular}

\begin{tabular}{|c|c|c|}
\hline \multicolumn{3}{|c|}{ Available nutrients (kg/ha) } \\
\hline $\mathbf{N}$ & $\mathbf{P}$ & $\mathbf{K}$ \\
\hline 131.33 & 21.79 & 144.28 \\
\hline 136.50 & 23.01 & 151.38 \\
\hline 137.66 & 26.26 & 155.68 \\
\hline 140.17 & 26.38 & 157.64 \\
\hline 145.83 & 31.15 & 162.07 \\
\hline 145.50 & 28.16 & 161.46 \\
\hline 159.67 & 32.08 & 163.44 \\
\hline 142.38 & 26.98 & 156.56 \\
\hline 1.32 & 0.55 & 0.99 \\
\hline 4.08 & 1.71 & 3.05 \\
\hline
\end{tabular}

Table.6 Isolation of inoculated microorganisms, enumeration of total count of bacteria and fungi in soil after harvest of ashwagandha

Treatments

\section{$\mathrm{T}_{1}$-Recommended dose of fertilizers} (control) N:P:K- 40:50:40 kg per ha + FYM- 5t/ha $T_{2}$-FYM(5t/ha)+Vermicompost$1.33 t / h a$ ( $N$ equivalent weight)

$\mathrm{T}_{3^{-}} \mathrm{T}_{1}+\mathrm{VAM}(25 \mathrm{~kg} / \mathrm{ha})$

$\mathrm{T}_{4}$-FYM (5 t/ha) + VAM (25 kg/ha)

$T_{5}-$ FYM (5 t/ha) +VAM (25 kg/ha) + (Panchagavya -3\% + Amruthapani $3 \%$ at 15 days interval)

T6- FYM (5 t/ha) + Azotobacter $(625 \mathrm{~g} / \mathrm{ha})+$ Azospirillum $(625 \mathrm{~g} / \mathrm{ha})+$ PSB (625g/ha) + VAM (25 kg/ha) $\mathrm{T}_{7}-\mathrm{T}_{6}+($ Panchagavya $-3 \%+$ Amruthapani $-3 \%$ at 15 days interval) Mean SEm \pm CD at $5 \%$

\begin{tabular}{c|c|}
$\begin{array}{c}\text { Azotobacter } \\
\text { Chroococcum } \\
\text { No. } \times \mathbf{1 0}^{\mathbf{4}}\end{array}$ & $\begin{array}{c}\text { Azospirillum } \\
\text { Brasilense } \\
\text { No. } \times \mathbf{1 0}^{4}\end{array}$ \\
CFU/g of soil & CFU/g of soil \\
\hline 14.00 & 10.50
\end{tabular}

Phosphate
Solubilising
Bacteria No. $x$
$\mathbf{1 0}^{\mathbf{6}}$ CFU/ gof soil
12.40

Bacteria
No. $\times \mathbf{1 0}^{\mathbf{6}}$
CFU/ g of
soil
49.00

\begin{tabular}{l|l}
18.00 & 14.72 \\
\hline
\end{tabular}

20.00

32.00

100.00

18.94
24.00
83.00

14

14.00
12.00
20.12
78.00

\begin{tabular}{|c|}
\hline 74.00 \\
\hline 56.00 \\
\hline 84.00 \\
\hline 110.00 \\
\hline
\end{tabular}

58.00

42.00

70.00

85.00

\begin{tabular}{|c|c|c|c|c|}
\hline 166.84 & 176.78 & 168.80 & 129.00 & 108.00 \\
\hline 174.25 & 192.23 & 178.46 & 134.00 & 124.00 \\
\hline $\mathbf{7 5 . 0 1}$ & $\mathbf{7 4 . 3 1}$ & $\mathbf{6 9 . 1 1}$ & $\mathbf{9 0 . 8 6}$ & $\mathbf{7 4 . 1 4}$ \\
\hline $\mathbf{1 8 . 0 2}$ & $\mathbf{1 9 . 9 5}$ & $\mathbf{1 8 . 9 1}$ & $\mathbf{8 . 5 8}$ & $\mathbf{8 . 5 0}$ \\
\hline $\mathbf{5 5 . 5 2}$ & $\mathbf{6 1 . 4 7}$ & $\mathbf{5 8 . 2 8}$ & $\mathbf{2 6 . 4 5}$ & $\mathbf{2 6 . 1 8}$ \\
\hline
\end{tabular}


Recommended dose of fertilizers (N: P: K40:50:40 kg/ha) + FYM (5 t/ha), which was on par with $\mathrm{T}_{3}(0.50 \mathrm{dS} / \mathrm{m})$ and $\mathrm{T}_{2}(0.49$ $\mathrm{dS} / \mathrm{m})$. The increase in $\mathrm{pH}$ might be due to increase in exchangeable aluminium in soil and application of inorganic fertilizer has reduced acidity. The increase in EC might be due to combined application of organic and inorganic fertilizers which enhanced exchangeable cations. Similar results are reported by Rajamani et al., (2007) in turmeric. Maximum organic carbon $(0.63 \%)$ was recorded in $\mathrm{T}_{7}-\mathrm{FYM}$ (5 t/ha) + Azotobacter (625 g/ha) + Azospirillum (625 $\mathrm{g} / \mathrm{ha})+$ PSB $(625 \mathrm{~g} / \mathrm{ha})+$ VAM $(25 \mathrm{~kg} / \mathrm{ha})+$ (Panchagavya-3\% + Amruthapani-3\% at 15 days interval), which was on par with $\mathrm{T}_{5}$ $(0.60 \%)$. This might be due to the reason that, their built up beneficial soil microbial population in the rhizosphere, increased plant residue decomposition and regular addition of bio-formulations especially by the synergetic effect both drench panchagavya and amrutpani have lead to the effective supply of organic matter. The results obtained in the present investigation are in agreement with earlier findings of Rajamani et al., (2007) in turmeric and Das et al., (2008) in stevia.

Nutrient status in soil after harvest varied significantly due to organic manures and bioinoculants sources of nutrients. The maximum soil nitrogen, phosphorous and potassium (159.67, 32.08 and $163.44 \mathrm{~kg} / \mathrm{ha}$, respectively) was observed in $\mathrm{T}_{7}$-FYM (5 t/ha) + Azotobacter (625 g/ha) + Azospirillum $(625 \mathrm{~g} / \mathrm{ha})+$ PSB $(625 \mathrm{~g} / \mathrm{ha})+$ VAM $(25$ $\mathrm{kg} / \mathrm{ha})+($ Panchagavya-3\% + Amruthapani$3 \%$ at 15 days interval), which was on par with $\mathrm{T}_{5}(145.83 \mathrm{~kg} / \mathrm{ha}$ of $\mathrm{N}, 31.15 \mathrm{~kg} / \mathrm{ha}$ of $\mathrm{P}$ and $162.07 \mathrm{~kg} / \mathrm{ha}$ of $\mathrm{K}$ ).

This might be due to the reason that, their built up of beneficial soil microbial population in the rhizosphere, increased plant residue decomposition and mineralization with regular addition of bio-formulations especially by the synergetic effect both drench of panchagavya and amrutpani have lead to the effective supply of nutrients. Application of VAM has lead to increased surface area for absorption and uptake of nutrients. Besides this Entrophospora sp. is also known to release growth hormones and enzymes, which help in translocation of insoluble nutrients to soluble form and increase their availability to plants resulting in increased content of major nutrients like $\mathrm{N}, \mathrm{P}$, $\mathrm{K}$ and micronutrients like $\mathrm{Fe}, \mathrm{Mg}, \mathrm{Mn}$, Mo and Co. The results obtained in the present investigation are in agreement with earlier findings of Rajamani et al., (2007) in turmeric, Das et al., (2008) in stevia and Sakhubhai et al., (2014) in buckwheat.

Microbial status in soil after harvest varied significantly due to organic manures and bioinoculants sources of nutrients.

The maximum bacteria and fungi count $\left(134.00 \times 10^{6}\right.$ and $124.00 \times 10^{3}$, respectively) were observed in the treatment in $\mathrm{T}_{7}-\mathrm{FYM}(5$ $\mathrm{t} / \mathrm{ha})+$ Azotobacter $(625 \mathrm{~g} / \mathrm{ha})+$ Azospirillum $(625 \mathrm{~g} / \mathrm{ha})+$ PSB $(625 \mathrm{~g} / \mathrm{ha})+$ VAM $(25$ $\mathrm{kg} / \mathrm{ha})+($ Panchagavya-3\% + Amruthapani$3 \%$ at 15 days interval), which was on par with $\mathrm{T}_{6}\left(129.00 \times 10^{6}\right.$ and108.00 $\times 10^{3}$, respectively).

The maximum population of Azotobacter chroococcum, Azospirillum brasilense and Phosphate solubilising bacteria $\left(174.25 \times 10^{4}\right.$, $192.23 \times 10^{4}$ and $178.46 \times 10^{6}$, respectively) was found in the treatment $\mathrm{T}_{7}-\mathrm{FYM}(5 \mathrm{t} / \mathrm{ha})+$ Azotobacter (625 g/ha) + Azospirillum (625 $\mathrm{g} / \mathrm{ha})+$ PSB $(625 \mathrm{~g} / \mathrm{ha})+$ VAM $(25 \mathrm{~kg} / \mathrm{ha})+$ (Panchagavya-3\% + Amruthapani-3\% at 15 days interval), which is found on par with the treatment $\mathrm{T}_{6}\left(166.84 \times 10^{4}, 176.78 \times 10^{4}\right.$ and $168.80 \times 10^{6}$, respectively).

These findings are in agreement with Maragatham and James, 2010, the population 
of Azospirillum, Phosphobacteria, Pseudomonas and VAM were higher because of the increase in microbial load due to application of bio-inoculants and panchagavya and amrutpani contain a lot of saprophytic bacteria, fungi, actinomycetes, yeasts, nitrogen fixers, 'P' solubilisers, growth promoting PGPRs, biocontrol agents and leading to microbial biotechnology in the soil. Similar results are reported by Srivatsava and Gobind (2007) in gladiolus and Sakhubhai et al., (2014) in buckwheat.

Higher root colonization (82.00\%) was observed in $\mathrm{T}_{7}$-FYM (5 t/ha) + Azotobacter $(625 \mathrm{~g} / \mathrm{ha})+$ Azospirillum $(625 \mathrm{~g} / \mathrm{ha})+$ PSB $(625 \mathrm{~g} / \mathrm{ha})+\mathrm{VAM}(25 \mathrm{~kg} / \mathrm{ha})+$ (Panchagavya-3\% + Amruthapani-3\% at15 days interval), which was on par with $\mathrm{T}_{6}$ (78.00\%), $\mathrm{T}_{5}(74.00 \%)$ and $\mathrm{T}_{4}(60.00 \%)$. Maximum number of chlamydospores (3174.50/100 $\mathrm{g}$ of soil) was observed in $\mathrm{T}_{7-}$ FYM (5 t/ha) + Azotobacter (625 g/ha) + Azospirillum (625 g/ha) + PSB (625 g/ha) + VAM $(25 \mathrm{~kg} / \mathrm{ha})+$ (Panchagavya $-3 \%+$ Amruthapani-3\% at 15 days interval), which was on par with $\mathrm{T}_{6}(3121.68 / 100 \mathrm{~g}$ of soil $), \mathrm{T}_{5}$ (2900.88/100 $\mathrm{g}$ of soil), $\mathrm{T}_{4}(2789.56 / 100 \mathrm{~g}$ of soil). The similar findings were noticed by Sakhubhai et al., (2014) in buch wheat, the single and dual inoculations of Glomus fasciculatum and Plant Growth Promoting Rhizobacteria, the consortium of these organisms were found superior in enhancing phosphorus content by mycorrhizal colonization and spore numbers in the root zone.

\section{References}

Ajay, P., Ramesh, K., Sammi, R. and Maji, B., 2005, Effect of nitrogen and farm yard manure on physiological parameter in ashwagandha (Withania somnifera Dunal.) and vertisol soil type. Indian $J$. Pl. Physiol., 10(4): 389-393.
Das, K., Dang, R. and Shivananda, T., 2008, Influence of bio-fertilizers on the availability of nutrients ( $\mathrm{N}, \mathrm{P}$ and $\mathrm{K}$ ) in soil in relation to growth and yield of Stevia rebaudiana grown in South India. Int. J. Appl. Res. Nat. Prod., 1: 2024.

Maheshwari, S. K., Sharma, R. K. and Gangrade, S. K., 2000, Response of ashwagandha (Withania somnifera) to organic manures and fertilizers in a shallow black soil under rainfed condition. Indian J. Agron., 45(1): 214216.

Majumdar, D. N., 1955, Withania somnifera Dunal. Part II Alkaloid constituents and their chemical characterization. Indian J. Pharm., 17(8): 158.

Maragatham, N. and James, M. G., 2010, Effect of land configuration techniques, NP levels and bioinoculants on soil available nutrients and soil microorganism in aerobic rice production in South India. $19^{\text {th }}$ World Congress of Soil Science, Soil Solutions for a Changing World, Brisbane, Australia. Published on DVD.

Pakkiyanathan, K., Pasha, Y. N., Narayan, R. Y. and Sathe, A., 2004, Effect of spacing and phosphorus on growth and root yield of ashwagandha (Withania somnifera Dunal.). Indian J. Hort., 61(2): 195-197.

Panchabhai, D. M., Bachkar, B. R., Ghawade, S. M. and Wankhade, S. G., 2005, Effect of nitrogen and phosphorus on growth and seed yield of ashwagandha (Withania somnifera Dunal). Orissa J. Hort., 33(1): $11-15$.

Rajamani, K., Kamalkumar, R., Shoba, N. and Balakrishnamurthy, G., 2007, Influence of organic manure and bio-regulates on growth and yield of turmeric var. BSR-2. South Indian Hort., 55(1-6): 170-178.

Rajasekar, S. and Elango, R., 2011, Effect of microbial consortium on plant growth and improvement of alkaloid content in Withania somnifera (ashwagandha). Current Botany, 2(8): 27-30.

Rana, R. S., Rana, S, S., Rana, M. C. and Rajendra, P., 2005, Influence of row 
spacing and fertility levels on tartary buckwheat (Fagopyrum tataricum Gaertn) under Sangla valley conditions of Himachal Pradesh. Himachal J. Agri. Res., 31(1): 3-7.

Rashmi, R., 2013, Integrated nutrient management in ashwagandha. M.Sc. (Hort.) Thesis, Univ. Horti. Sci., Bagalkot.

Ravikumar, M., Venkatesh, J., Munikrishnappa, P. M. and Gangadharappa, P. M., 2010, Effects of microbial inoculants in combination with organic manures and inorganic fertilizers on yield and quality of coleus. J. Med. Arom. Pl. Sci., 32(4): 362-365.

Ravikumar, M., Venkatesha, J., Niranjana, K. S. and Gurumurthy, B. R., 2012, Effect of integrated nutrient management on tuber yield and quality and nutrient uptake in Coleus forskohlii Briq. J. Root Crops, 38(2): 142-146.

Sakhubai, H. T., Laxminarayan, H. and Chaya. P. P., 2014, Effect of bio-fertilizers on growth, yield and quality of buckwheat. $J$. Agri. Life Sci., 1(2): 86-91.

Sandhya, A., Vijaya, T., Sridevi, A. and Narasimha, G., 2013, Influence of vesicular arbuscular mycorrhizal and phosphate solubilizing bacteria on growth and biochemical constituents of Marsdenia volubilis. Afri. J. Biotechnol., 12(38): 5648-5654.

Savitha, M. M., Mamatha, B. and Shivananda, T. N., 2009, Phytochemistry and medicinal uses of Withania somnifera (L.). Biomed., 4(2): 123-129.

Shinde, A., Gahunge, P., Singh, P., Kumar, R. S. and Khemani, N., 2013, Effect of inorganic fertilizers and organic manures on growth, quality and yield of ashwagandha (Withania somnifera Dunal) cv. Jawahar ashwagandha-20. Annals of Pharmacy and Pharmaceutical Sci., 4: 13-16.

Shrivatsav, A. K. and Sahu, P. K., 2013, Yield and quality parameter of alkaloids of Withania somnifera L. Dunal. Int. J. Agron. Pl. Product., 4(12): 3246- 3254.

Snezana, O., Zeljko, D., Mico, O. and Snezana, D., 2012, Effect of Microbiological fertilizer and soil additive on yield of buckwheat (Fagopyrum esculentum Moench) under high altitude conditions. Ratar. Povrt., 49(3): 302-306.

Somnath, S., Bhaskar, S. and Sreenivasmurthy, C. A., 2005, Influence of FYM, inorganic fertilizer (NPK) and sources of potassium on yield of Plectrantus forskohlii. J. Med. Arom. Pl. Sci., 27: 16-19.

Sreerekha, M. V., Patel, K. V., Bhatnagar, R. and Sriram, S., 2004, Distribution of total withanolides in various plant parts of ashwagandha (Withania somnifera) accessions as influenced by light and dark cycle. J. Med. Arom. Pl. Sci., 26: 681683.

Srivastava, R. and Gobind, M., 2007, Influence of bio-fertilizers on growth and flowering in gladiolus cv. American beauty. Acta Hort., 23(5): 183-188.

Vajantha, B., Umadevi, M., Patnaik, M. C. and Rajkumar, M., 2014, Dry matter production, root characters and seed yield of ashwagandha (Withania somnifera L.) as influenced by panchakavya. J. Global Biosci., 3(4): 354-358.

\section{How to cite this article:}

Pramodkumar, T., Mukund Shiragur and Chandrakant, B. 2018. Effect of Bio-Inoculants on Growth, Dry Root Yield and Quality in Ashwagandha (Withania somnifera L. Dunal.). Int.J.Curr.Microbiol.App.Sci. 7(09): 2203-2212. doi: https://doi.org/10.20546/ijcmas.2018.709.272 